\title{
ANALYSIS OF FACTORS AFFECTING THE SATISFACTION AND LOYALTY OF THE USE OF CARGO SERVICES: A CASE STUDY OF PT. BEX
}

\author{
Andika Arief ${ }^{\star}$, Simanjuntak Megawati, Kirbrandoko, Researchers \\ Business School, Bogor Agricultural Institute, Bogor, Indonesia \\ *E-mail: arifandika89@gmail.com
}

\begin{abstract}
The logistics industry is an important industry that plays an important role for other industries. Business uncertainty currently has an impact on almost all industries. Likewise, the logistics industry has also been explained to experience a decline in sales in almost every year. This study uses the PLS approach to solve research problems. The results of the study show that there are several variables that have an important influence on customer satisfaction and loyalty.
\end{abstract}

\section{KEY WORDS}

Intimacy cargo, logistics, satisfaction, loyalty.

The logistics industry is an important industry that plays an important role for other industries. The logistics company becomes the liaison for other companies in order to deliver raw materials, finished goods and or other goods to other targeted companies. Rahayu (2014) explained that the logistics industry could develop if there were economic developments and increased trade in a country.

Economic development into the factors described can affect the development of other businesses, especially the logistics business. Amid the uncertainty of the country, Indonesia managed to grow an average of 5.61 percent since 2010-2017. This is the basis that Indonesia's business climate can continue to grow at any time (Figure1).

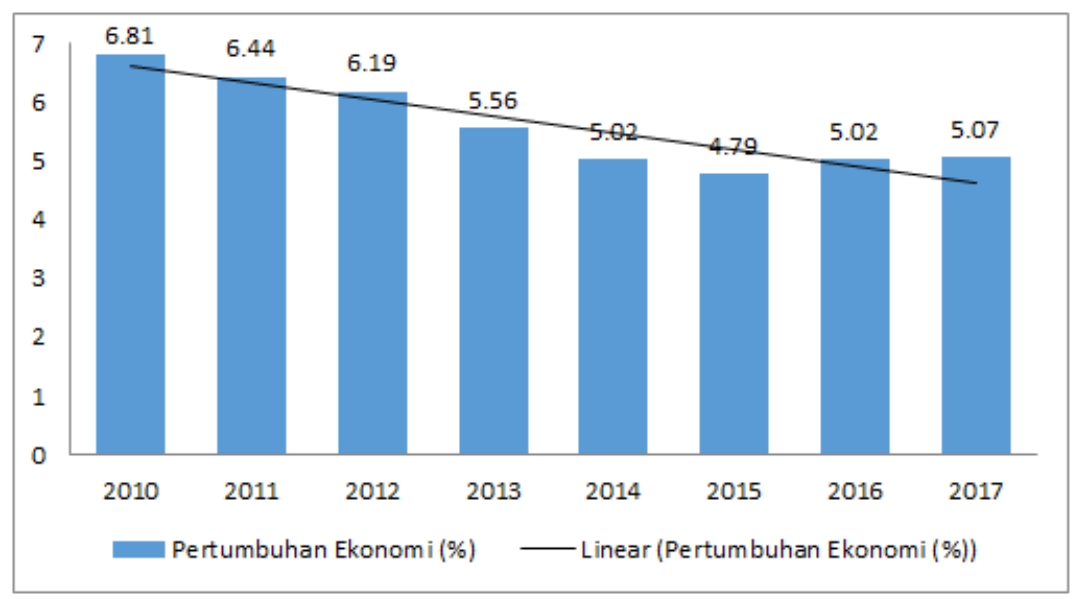

Figure 1 - Indonesia's Economic Growth in percent (Source: Central Statistics Agency, 2017)

From Figure 1 it is known that the Indonesian economy tends to decline due to several important moments including in 2011 a crisis in America and Europe which affected Asia including Indonesia. In addition, in 2014 the rupiah exchange rate fell again, causing Indonesia's economic growth to slow down.

The progress of the logistics industry in Indonesia is inseparable from the influence of technological developments and information systems. It is known that the multiplier effect of the ecommerce business has an influence on the growth of the logistics industry by 30 percent (Asperindo 2017). This is due to the increasing use of e-commerce and people who want to be more practical. 
The logistics industry that continues to grow and gets bigger every time causes many business actors to glance and are interested in being involved in the business. This of course can have an influence on the increasing level of competition between companies. Therefore we need a step that can win the competition in the logistics industry.

PT BEX is a company engaged in the logistics industry that has been established since 2000. PT BEX has a main focus on business activities related to the distribution of goods that require special handling and time. This is the basic force for companies to win competition from similar companies.

PT BEX is currently conducting program intimacy. This concept is part of marketing activities related to the ability of service providers to be more accepted and recognized as permanent partners by their customers. Basically, the more accepted the marketer or company, the better the interaction between the increase in the output increases as well. From these considerations, it was considered important to make several questions, among others: (1) What is the physical response, reliability, responsiveness, assurance, intimacy towards satisfaction in using cargo at PT BEX? (2) What is the effect of satisfaction on loyalty in using cargo at PT BEX? (3) How to formulate a management policy in increasing customer loyalty?

\section{LITERATURE REVIEW}

Products represent all economic activities that are produced from physical forms but can be produced together to provide added value to the product (Zethaml \& Bitner 1996). Kotler (2010) describes services that can be offered and are intangible. This is also discussed by Nasution (2004) which states that providing services related to the economy that produces is not in accordance with what is given to customers.

Service quality is a measure that is considered. The level of service provided is in accordance with expectations (Tjiptono 2006). Payne (2007) states that service quality supports organizations in providing services to meet needs exceeding customer expectations. Parasuraman et al. (1998) state a quality model that describes the expectations of customers related to expectations and perceptions of perception.

Physical Evidence presented by Payne (2000) about the components in it There is a physical environment provided by the company which then provides services that can be performed by each other. Physical evidence is the physical environment at the time the product is made. Lupiyoadi (2013). Zeithaml et al (2009) states that the physical evidence of the product represents all aspects that contain the physical organization and communication of the product offered.

Reliability is the company's ability to provide services that are in accordance with the promised, appropriate and reliable (Lupiyoadi 2001). Performance in service is required to be in accordance with customer expectations or in accordance with what was promised in the service. Where this is often related to timeliness, attitude and high accuracy.

Responsiveness is an ability to help and provide fast and appropriate to customers (Lupiyoadi 2001). This is confirmed by the statement of Tjiptono (2010) which explains that responsiveness is the desire of the staff to help customers and provide the best service.

Intimacy is the closeness of someone who is done by sharing deep thoughts and feelings (Atwater 2009). This is explained by Sternberg (2006) which states that intimacy is an emotional element in a relationship that involves self-disclosure, which later is expected to be able to make a connection and trust (emotional).

Price is defined as the amount of money charged for the purchase of a product or service (Kotler \& Armstrong 2012). Lamb (2001) says prices are a measure that must be given by consumers (buyers) to get a product. Prices are often the most flexible element among the four marketing mix elements. Dharmesta (2008) states that price is the amount of money needed to get a number of combinations of products and services.

Customer satisfaction is an important indicator of a business activity. Kotler (2010) customer satisfaction is a response from customers for evaluation of perceived nonconformities between perceived expectations and product performance. 
Consumer loyalty is consumer loyalty to companies, brands and products (Rangkuti 2002). Customer loyalty is an important thing that can influence the relationship between consumers and companies (Costabile et al. 2002).

Research Hypothesis. This study has 7 hypotheses, among others: H1: Physical evidence that affects consumer satisfaction, H2: Strengthening reliability of customer satisfaction, H3: Responsiveness to customer satisfaction, H4: Guarantee of customer satisfaction, H5: Guarantee satisfaction with customer satisfaction, H5: H6: Intimacy aimed at customer satisfaction, H7: Priority satisfaction with consumer loyalty.

\section{METHODS OF RESEARCH}

This research was conducted with consumer objects from PT BEX headquartered in Jabodetabek. This was chosen because the majority of consumers who carry out large amounts of shipping activities are in the area. In addition, this research will be conducted from November to December 2018.

This research uses quantitative and associative approaches. Quantitative approach is a method based on the use of numbers that starts from data collection, analysis and appearance of the results of the study (Arikunto 2013) while associative is a method used to explain the causal relationship and the effect of each variable tested by hypothesis (Sugiyono 2013).

The sample of this study amounted to 120 respondents. Hair et al (2010) stated that sampling was a good sample in a study if the number was 5-10 times the indicator used in the study.

The scale of research is used as a basis for reference agreement in determining the range of a measuring instrument. This study used the Likert scale Sumarwan (2017): Strongly agree (4), agree (3), Disagree (2), Strongly Disagree (1).

The data collection technique used in this study was purposive sampling, where researchers were required to make eligible sample criteria to be chosen in the study. Criteria set by consumers who have used the service at least 3 times and Consumers who make

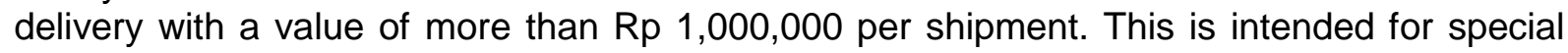
consumers.

In this study using descriptive analysis. According to Sumarwan (2017), descriptive is a research method whose purpose is to describe the characteristics of an object of people, groups, organizations and the environment. In this study descriptive analysis is intended to find out an explanation of the state of the object of research, besides that this method is used to find the relationship of existence of variables without making comparisons with others.

Partial Least Square (PLS) is a regression-based method that was introduced for the creation and development of models and methods for the social sciences with an approach oriented to the prediction of Ghozali (2006). PLS assumes that research data is free of distribution, meaning that research data does not refer to one particular distribution (eg normal distribution). PLS is an alternative method of SEM that can be used to overcome the problem of relationships between complex variables (Hair et al 2010).

\section{RESULTS AND DISCUSSION}

PT Bersaudara Express Cargo (bexindo) is a logistics and distribution company established in Jakarta on March 14, 2000. In its first year of operation, BEX has facilitated all the health equipment of the company it manages throughout Indonesia. The second year and so on until now, BEX has increased its market and proudly succeeded in leading companies like you.

Indicator validity testing is a test conducted to ensure the indicators used in the research model are appropriate and appropriate when used. In the partial least square method a limit of 0.5 is used to state that an indicator is valid (Hair et al 2010). is an outer test of the partial least square model. In addition, by testing validity, it is expected to get indicators that can be 
used as recommendations related to contributions to the variables. An overview of the validity of indicators is presented in Table 5.

Table 4 - Description of respondents

\begin{tabular}{|c|c|c|c|}
\hline Category & & Total $(n)$ & Percentage (\%) \\
\hline \multirow{5}{*}{ Gender } & Male & 102 & 85 \\
\hline & Female & 18 & 15 \\
\hline & Medical devices & 36 & 30 \\
\hline & Pharmacy & 45 & 38 \\
\hline & Electronic & 6 & 5 \\
\hline \multirow[t]{7}{*}{ Types of goods } & Chemistry & 5 & 4 \\
\hline & Fashion & 10 & 8 \\
\hline & Machine & 15 & 13 \\
\hline & Other products & 3 & 3 \\
\hline & Bekasi & 18 & 15 \\
\hline & Bogor & 9 & 8 \\
\hline & Depok & 14 & 12 \\
\hline \multirow[t]{5}{*}{ Location } & Jakarta & 49 & 41 \\
\hline & Semarang & 5 & 4 \\
\hline & Surabaya & 4 & 3 \\
\hline & Tangerang & 21 & 18 \\
\hline & Owner & 3 & 3 \\
\hline \multirow{5}{*}{$\begin{array}{l}\text { Position } \\
\text { Respondents }\end{array}$} & Head of Warehouse & 13 & 11 \\
\hline & Manager & 51 & 43 \\
\hline & SPV & 38 & 32 \\
\hline & Staff & 15 & 13 \\
\hline & $<100 \mathrm{~kg}$ & 4 & 3 \\
\hline \multirow{4}{*}{ Shipping Weight } & $100-250 \mathrm{Kg}$ & 47 & 39 \\
\hline & $250-500 \mathrm{Kg}$ & 37 & 31 \\
\hline & $>500 \mathrm{Kg}$ & 47 & 39 \\
\hline & $1.000-10.000$ & 7 & 6 \\
\hline Cost & $10.000-100.000$ & 42 & 35 \\
\hline \multirow[t]{3}{*}{ (in thousand Rupiah) } & $100.000-500.000$ & 28 & 23 \\
\hline & $>500.000$ & 43 & 36 \\
\hline & $1-4$ & 41 & 34 \\
\hline \multirow{4}{*}{ Vendor Options (Competitors) } & $5-7$ & 58 & 48 \\
\hline & $8-9$ & 4 & 3 \\
\hline & $>10$ & 17 & 14 \\
\hline & By Request & 49 & 41 \\
\hline \multirow{4}{*}{ Order } & Daily & 44 & 37 \\
\hline & Weekly & 25 & 21 \\
\hline & Mountly & 2 & 2 \\
\hline & $1-5$ & 6 & 5 \\
\hline \multirow{3}{*}{ Banyak Kiriman dalam Sebulan } & $6-10$ & 45 & 38 \\
\hline & $11-15$ & 25 & 21 \\
\hline & $>16$ & 44 & 37 \\
\hline
\end{tabular}

Based on Table 5, information is obtained that there are several indicators in each variable that do not match the criteria that have been determined (output> 0.5). The physical evidence variable is known to consist of 8 indicators. There are only 3 indicators that are valid so that the other 5 indicators are deleted. The 5 indicators are BF1, BF2, BF3, BF4 and BF6. Variables of physical evidence are known to consist of 7 indicators. Only 5 indicators are valid so that the other 2 indicators are deleted. The 2 indicators are DT1 and DT2. the price variable is known to consist of 4 indicators. All indicators of the price variable are all declared valid. Intimate variable is known to consist of 8 indicators. All indicators of intimacy variables are all declared valid. The Variable Guarantee variable consists of 5 indicators. 4 of the 5 indicators are declared valid while one indicator is issued, namely JA1. And the physical evidence variable is known to consist of 8 indicators. There are only 7 indicators that are valid so that one other indicator is deleted. The indicators are $\mathrm{KH} 7$. The satisfaction variable is known to consist of 3 indicators. All indicators of the overall satisfaction variable are declared valid and the loyalty variable is known to consist of 5 indicators. All indicators of the loyalty variable are all declared valid. 
Table 5 - Test Validity Indicators

\begin{tabular}{|c|c|c|c|c|c|}
\hline Indicator & Output & Information & Indicator & Output & Information \\
\hline BF1 & -0.275 & Invalid & IN6 & 0.716 & Valid \\
\hline BF2 & 0.393 & Invalid & IN7 & 0.577 & Valid \\
\hline BF3 & 0.138 & Invalid & IN8 & 0.525 & Valid \\
\hline BF4 & 0.412 & Invalid & JA1 & 0.482 & Invalid \\
\hline BF5 & 0.530 & Valid & JA2 & 0.645 & Valid \\
\hline BF6 & 0.343 & Invalid & JA3 & 0.501 & Valid \\
\hline BF7 & 0.853 & Valid & JA4 & 0.882 & Valid \\
\hline BF8 & 0.664 & Valid & JA5 & 0.743 & Valid \\
\hline DT1 & 0.390 & Invalid & $\mathrm{KH} 1$ & 0.523 & Valid \\
\hline DT2 & 0.467 & Invalid & $\mathrm{KH} 2$ & 0.777 & Valid \\
\hline DT3 & 0.764 & Valid & KH3 & 0.763 & Valid \\
\hline DT4 & 0.748 & Valid & $\mathrm{KH} 4$ & 0.845 & Valid \\
\hline DT5 & 0.809 & Valid & KH5 & 0.776 & Valid \\
\hline DT6 & 0.597 & Valid & KH6 & 0.758 & Valid \\
\hline DT7 & 0.746 & Valid & $\mathrm{KH} 7$ & -0.238 & Invalid \\
\hline $\mathrm{H} 1$ & 0.619 & Valid & $\mathrm{KH} 8$ & 0.381 & Invalid \\
\hline $\mathrm{H} 2$ & 0.822 & Valid & KP1 & 0.822 & Valid \\
\hline $\mathrm{H} 3$ & 0.556 & Valid & KP2 & 0.853 & Valid \\
\hline $\mathrm{H} 4$ & 0.884 & Valid & KP3 & 0.888 & Valid \\
\hline IN1 & 0.707 & Valid & LY1 & 0.689 & Valid \\
\hline IN2 & 0.802 & Valid & LY2 & 0.743 & Valid \\
\hline IN3 & 0.850 & Valid & LY3 & 0.783 & Valid \\
\hline IN4 & 0.678 & Valid & LY4 & 0.817 & Valid \\
\hline IN5 & 0.824 & Valid & LY5 & 0.535 & Valid \\
\hline
\end{tabular}

Validity and reliability testing of variables is an important thing that needs to be done to ensure the accuracy and reliability of the variables used in the research model. Average Variance Extracted (AVE) is used to determine variable validity, with a limit of $>0.5$ (Hair et al. 2010). Composite reliability is used to determine the reliability of variables, with a limit of> 0.7 (Hair et al. 2010). The variable validity and reliability test is presented in Table 6.

Table 6 - Test Validity and Reliability of Variables

\begin{tabular}{ccc}
\hline Variable & Composite Reliability & Average Variance Extracted (AVE) \\
\hline Bukti Fisik & 0.802 & 0.580 \\
Daya anggap & 0.860 & 0.555 \\
Harga & 0.817 & 0.537 \\
Intimacy & 0.893 & 0.516 \\
Jaminan & 0.796 & 0.503 \\
Kehandalan & 0.884 & 0.564 \\
Kepuasan & 0.890 & 0.730 \\
Loyalitas & 0.841 & 0.519 \\
\hline
\end{tabular}

Based on Table 6, it is known that all variables are all valid, which is indicated by the output value that has exceeded 0.5 . In addition to the composite composite output also gives results above 0.7 , which means that all variables are declared reliable.

RSquare which is a picture related to the description of a depicted model of its constituent variables (Sugiyono 2010). In this case there is no limit or value that describes a model well, the resulting RSquare value is presented in Table 7.

Table 7 - R Square

\begin{tabular}{cc}
\hline Variable & R Square \\
\hline Satisfaction & 0.935 \\
Loyalty & 0.173 \\
\hline
\end{tabular}

From Table 7, the satisfaction model of PT Bex's customers can be described as 93.5 percent of the variables in the model, while the remaining 6.5 percent is predicted by outside models. In the loyalty model it is known that only 17.3 percent can be depicted while the remaining 82.7 percent is predicted from outside the model. 
Tested the relationship between variables used in the study. Besides testing is done to determine the significance of each hypothesis that is determined. The results of hypothesis testing are presented in Table 8.

Table 8 - Testing of Research Hypotheses

\begin{tabular}{lllll}
\hline Variable & Estimate & T Stat & P Values & Information \\
\hline Physical Proof -> Satisfaction & -0.114 & 0.650 & 0.516 & Not significant \\
Response -> Satisfaction & 0.082 & 1.967 & 0.050 & Significant \\
Price $->$ Satisfaction & 0.206 & 2.970 & 0.003 & Significant \\
Intimacy - Satisfaction & 0.300 & 3.960 & 0.000 & Significant \\
Guarantee -> Satisfaction & 0.025 & 0.143 & 0.886 & Not significant \\
Reliability -> Satisfaction & 0.448 & 5.419 & 0.000 & Significant \\
Satisfaction -> Loyalty & 0.416 & 6.701 & 0.000 & Significant \\
\hline
\end{tabular}

The relationship of physical evidence variables to satisfaction variables has insignificant results $(0.650>1956)$. This is because customers do not care about what belongs to PT Bex, such as having a warehouse, complete fleet, number of branches and channels. This is exemplified by companies in the same industry not having their own fleet but they still use their services. Silitonga (2010) explained that physical evidence only fits the description in the initial stages where as a form of perception that the company is able to provide good service.

The relationship of responsiveness variables to satisfaction variables has a positive (0.082) and significant $(1,967>1956)$. This is related to the company's performance in the eyes of customers. Exemplified through the return of receipts, the position of goods, claims in accordance with expectations, Where some customers require delivery order letters, receipts as proof that the goods have arrived and are needed for billing invoices from customers to their business partners. Responsiveness to claims is also very important considering the price of the goods sent is relatively expensive and requires special handling. Yuniarti (2014) explains that the responsiveness of employees is an important part of increasing customer satisfaction because customers basically expect attention from the company they trust.

The relationship of the price variable to the satisfaction variable has a positive $(0.206)$ and significant $(2,970>1956)$. Price is an important instrument to attract customers and make customers satisfied. Customers will be satisfied if shipping costs can compete with better service quality and benefits. On the other hand, PT Bex needs to know the budget for the range of product delivery from each customer.

The relationship of intimacy variables to satisfaction variables has a positive $(0.300)$ and significant (3.960> 1956). This can be seen from the closeness so that it builds a sense of reluctance to customers so that it can cover up dissatisfaction with the services of PT BEX. Intimacy is also very useful when getting a shipping project where PT BEX employees get the price offered by competitors so PT BEX can secure the competitor's shipping price.

The relationship of the guarantee variable to the satisfaction variable has a nonsignificant result $(0.143>1956)$. The guarantee role is proven in the shipping process, this can be seen from the PIC of the driver and driver accompanying the customer's goods. In a study by Bakrie (2010), it was explained that the customers did not terminate the guarantee if the company could prove through the agreement and the ability (professionalism) to the customer.

The relationship of the reliability variable to the satisfaction variable has a positive (0.448) and significant $(5,419>1956)$. Reliability is very influential considering the target market is handling specialist items which require special handling and relatively fast time. The re-checking of shipments in the warehouse to penalize missrays is PT BEX's own points because of the large number of items sent by customers and allows them to be exchanged with other customers because the items sent by the items are the same between customers. In Mosahab's research (2010), it was explained that employee reliability had an important role in increasing employees due to the reliability associated with the company's ability to operate. 
The relationship of satisfaction variables to loyalty variables has a positive $(0.416)$ and significant $(6,701>1956)$. This explains that PT Bex is able to provide satisfaction to customers with a series of activities. On the other hand loyalty from customers has begun to take shape as consumers have been satisfied. Kusumawati (2015) explained that customer satisfaction can encourage customers to be loyal to company services, the benefits of this can be useful as a free promotional machine due to the effects of recommendations.

\section{MANAGERIAL IMPLICATIONS}

There are several managerial implications in this study, Companies that carry out cargo business operations get some important recommendations for the company. The company should make an automatic notification application about the position of the company, this is to increase customer confidence in the products entrusted to the company. Implementing an SOP for services in a rangkan increases responsiveness with a time limit not exceeding 10 minutes, with the time limit it is expected that the company's performance to serve customers becomes better. The company needs to formulate a new price by integrating with similar companies, this is considered an accurate step in order to reduce the company's costs. Companies can approach important stakeholders to ensure that companies are chosen.

\section{CONCLUSION AND SUGGESTIONS}

In this study, several conclusions related to the formulation of the problem that have been determined: (1) prove that physical and collateral are not related to customer satisfaction. Whereas price, responsiveness, reliability, intimacy have a significant influence on customer satisfaction, (2) The relationship of customer satisfaction is recognized as having a positive and significant influence on customer loyalty. Although most research models exist, (3) Companies find satisfaction providing a large part of loyalty. So from that the company needs to maintain customer loyalty by optimizing all factors that have a significant influence.

Suggestions in this study need several important things, including: (1) now companies need to focus on the business to business model. This relates to the characteristics recorded at this time describing the model; (2) companies also need to consider startup businesses that have a large relationship with product delivery. This can be used as a potential in increasing company sales; (3) further research can evaluate the expansion of the retail market segment or B to B with an increase of $40-50 \%$ in 2019.

\section{REFERENCES}

1. Alfiano V, Ngatno N. 2012. Pengaruh Harga and Kualitas Jasa Jne Ekspress terhadap Loyalitas Pelanggan Melalui Kepuasan Pelanggan sebagai Variable Intervening. Journal Administrasi Bisnis. 3(2); 21-31.

2. Atwater E, Duffy K. 2005. Psychology for living: Adjusment, Growth and Behaviour Today (8th Edition). Pearson Prentice. New Jersey.

3. Coltman R. Gattorna J. Whiting S. 2010. Realigning service operations strategy at DHL express. Journal Informations. 4(2); 52-61.

4. Costabile M, Raimondo MA. Miceli G. 2002. A Dynamic Model of Customer Loyalty. Proceedings of the 31st Annual Conference of the European Marketing Academy.

5. Dharmesta. 2008. Manajemen Pemasaran Modern. Edisi Kedua.Liberty. Yogyakarta.

6. Hair JF, Black WC, Babin BJ, Anderson RE. (2010), Multivariate Data Analysis, 7th ed. Pearson Prentice Hall, New Jersey.

7. Kavaliaskiena LM. 2014. Consumer Satisfaction with the Quality of Logistics Services. Elsevier Journal. 5(110) ; 330-340.

8. Kotler P, Amstrong G. 2012. Manajemen Pemasaran. Ghalia. Jakarta.

9. Lamb C. 2001. Pemasaran Edisi Pertama, Salemba Empat. Jakarta. 
10. Lupiyoadi R. 2013. Manajemen Pemasaran Jasa Berbasis Kompetensi (Edisi 3). Jakarta: Salemba Empat.

11. Nasution MN. 2004. Manajemen Jasa Terpadu. Jakarta: PT Ghalia Indonesia.

12. Payne A. 2008. The Essence of Service Marketing (Pemasaran Jasa). Jakarta: Salemba Empat.

13. Prasetyo FA. Analisis Perbandingan Service Quality antara Jne and J\&T Ekpress. Journal Logistik. 4(1); 34-43.

14. Rangkuti F. 2002. Measuring Customer Satisfaction. Jakarta: Gramedia Utama.

15. Sternberg RJ. 2007. Psikologi kogitif (4th ed). Pustaka Pelajar. Yogyakarta.

16. Sugiyono. 2013. Metode Penelitian Pendidikan Pendekatan Kuantitatif, Kualitatif, and R\&D. Bandung: Alfabeta.

17. Sumarwan U. 2010. Pemasaran Strategik (Prespektif Value-Based Marketing \& Pebgukurab Kinerja). IPB Pres. Bogor.

18. Tjiptono F. 2006. Manajemen Jasa Edisi Pertama. Yogyakarta: Andi.

19. Zeithaml VA, Bitner MJ. 1996. Delivering and Performing Service, Part Five, Service Marketing, International Ed. Amerika: The McGraw-Hill Companies. 